\title{
Financial Problems of Small and Medium Enterprises (SMEs) and Solution Suggestions
}

\author{
Küçük ve Orta Ölçekli İşletmelerin (KOBİ) Finansal Sorunları ve Çözüm Önerileri
}

\section{Sevgi SÜMERLİ SARIGÜL}

Dr. Öğr. Üyesi, Kayseri Üniversitesi, TBMYO,

ssumerli@kayseri.edu.tr

https://orcid.org/0000-0002-3820-6288
Makale Başvuru Tarihi / Received: 15.05.2021

Makale Kabul Tarihi / Accepted: 18.06.2021

Makale Türü / Article Type: Araştırma Makalesi
Anahtar

Kelimeler:

$K O B \dot{I}$,

KOBI'lerin

Sorunlarl,

Finansal Sorunlar.

Keywords:

SME,

Problems of SMEs,

Financial Problems.

\section{ÖZET}

KOBİller ülke ekonomilerinin \%60-95 oranlarında değișen temel dinamikleridir. Elde ettikleri ekonomik değer, gerçekleștirdikleri istihdam, sahip olduklarl ekonomik esneklik, ürettikleri mal ve hizmet çeşitliliği gibi nedenlerden dolayl ülkelerin en önemli ekonomik güçlerinden birisi hatta en önemlisidir. KOBİlerin büyük ölçekli işletmelere göre bazı üstünlükleri yani avantajları bulunmaktadır. Bunun yanı sıra büyük ölçekli işletmelere göre bazı dezavantajlara da sahiptirler. Bu çalı̧̧mada KOBİ'lerin kuruluş ve faaliyet süreçlerinde karșılaștıkları temel sorunların ortaya konmasını ve bu sorunlara çözüm önerileri getirilmesini amaçlamaktadır. Bu kapsamda akademik yazında daha önce yapılan çalıșmalar incelenmiştir. İlgili çalıșmaların bulguları ve sonuçları değerlendirilerek çalıșma içerisinde analiz edilmiștir. KOBİ'lerin üretim, pazarlama, rekabet, ar-ge, teknolojik yapı, planlama, karar alma, denetim, organizasyon, yönetim, finans, insan kaynakları, bürokrasi, mevzuat, vd. sorunları incelenmiştir. Çalışma neticesinde KOBİlerin en önemli sorununun finansal sorunlar olduğu anlașllmıștır. Finansal sorunların diğer sorunları doğrudan etkilediği görülmüștür. Ayrıca uzman personel ve yönetici istihdamının düşük seviyede olması durumunun da diğer sorunları doğrudan etkilediği sonucuna ulaşılmıştır.

\section{ABSTRACT}

SMEs are the basic dynamics of the country's economies, which vary by 60-95\%. It is one of the most important economic strengths of countries, even the most important, due to the economic value they obtain, the employment they perform, the economic flexibility they have, the variety of goods and services they produce. SMEs have some advantages over large-scale enterprises. In addition, they also have some disadvantages compared to large-scale enterprises. This study aims to reveal the main problems SMEs encounter in their establishment and activity processes and to offer solutions to these problems. In this context, previous studies in the academic literature have been examined. The findings and results of the relevant studies were evaluated and analyzed within the study. SMEs' production, marketing, competition, $R \& D$, technological structure, planning, decision-making, audit, organization, management, finance, human resources, bureaucracy, legislation, etc. problems have been studied. As a result of the study, it was understood that the most important problem of SMEs is financial problems. It has been observed that financial problems directly affect other problems. In addition, it was concluded that the low level of expert staff and manager employment also directly affects other problems. 


\section{INTRODUCTION}

The most important power element for governments is the economy. Therefore, in order to establish a strong economy, a strong economic sector/market must be owned. For this, effective economic policies are needed. In this context, in some cases the public sector must be a direct entrepreneur, in some cases support the entrepreneur, or even withdraw from the market or intervene indirectly in order to create free entrepreneurs. (Mecek, 2013: 495; Mecek ve Akın, 2014: 2).

Economic actors need to be supported and guided because the economy is the most fundamental asset element for states. The services produced, the policies developed, the legal legislation established and the plans carried out must be economy-based. Otherwise, it will indicate that countries lose their competitiveness first economically and then in general, and their progress slows or even declines.

Since SMEs are the main dynamics and competitive elements of the country's economies, their problems should be identified early and quickly and effective solutions should be provided (Özgener, 2003: 133-161). In particular, the detection and resolution processes of financial problems, which are the most fundamental and inclusive of these problems, are critical. Based on local, regional and global developments and policies, policies related to SME problems need to be constantly updated. For example, globalization movements, liberalization and securitization policies in the world economy have brought with them multifaceted innovations in international markets (Çelik, 2007: 29). However, considering the level reached by financial markets, it is seen that non-bank institutions that will support Small and Medium Enterprises (SMEs) financially have not developed to the desired extent.

The unstable structure of the Turkish economy, the inadequacies in legal and institutional regulations and the factors that spread and hindered these developments for many years also constitute an obstacle to the elimination of this negativity. Therefore, an effective policy should be established and implemented to solve these problems in a holistic manner. Considering the global economic structure, the establishment or increase of capacity of a business provides certain opportunities for the economies of the country. However, increased competition, persistence in quality and pressures to achieve lower costs represent the main challenges facing businesses around the world.

Small and Medium Businesses often don't have the size, financial resources and capacity to handle complex business management issues. SMEs are a very important resource for all countries in terms of providing new business opportunities, export and economic contributions. In developing countries, the opportunity to benefit from financing is seen as an important element for SMEs to be successful in creating productive capacity, competing and opening up new business areas.

The first of the main arguments that enable SMEs to gain importance is that SMEs adopt a competitive free market economy. The free-market economy aims to realize the production required by the globalization process with low prices and high quality. The second argument is that before globalization, large-scale production and profitable and efficient production were advocated, and it was started to be advocated with small-scale productions in the process (Şeker, Doğan and Elitaş, 2016: 202). SMEs have an important role in the economies of industrialized nations. This also applies to emerging and transitional economies. SMEs are very important not only in terms of the products and services produced, but also in terms of the job opportunities created. SMEs play a key role in the development of technology and knowledge-driveneconomies. It is also vital in the process of bringing innovation to the market. SMEs are an important way to achieve new economic growth, increase international competitiveness and create new business opportunities.

\section{CONCEPTUAL and THEORETICAL STRUCTURE of SMES}

Small and medium-sized enterprises are simply called "SME" (http://www.kobi.org.tr). It is very difficult to talk about a common definition of SMEs. In the current literature, this definition is made differently according to the sectoral structures of the enterprises. This is because the concept of scale size varies from country to country (Oktay and Güney, 2002: 2). The level of development of the 
country is a significant obstacle to such classification (Oktav vd., 1990: 1). However, common criteria for determining the concept of "small scale" for industrial enterprises can be found in many countries (Bulmuş et al., 1990: 14).

Small and Medium Enterprises; they are businesses whose capital is limited, their production is based mainly on manual labor, technological changes in the environment cannot be included due to lack of capital, they have difficulty in competition due to the inability to create an economy of scale, but have the ability to make quick decisions. As the main factors affecting the definition of SME in general, the level of industrialization, the technology used, the size of the market, the line of business in operation, the production technique used, time, economic level, characteristics of the goods produced, number of workers, organizations and researches can be listed. (Balı ve Gümrükçü, 2017: 3). However, the different criteria used in the definitions are not collected properly and regularly given at the macro level, and series can not be created (Özdemir vd., 2006: 35).

In Turkey, family companies are generally among the companies that make up SMEs. Family business; it is a company (http://www.isletme.biz) founded to provide for the family and/or to prevent the disintegration of the inheritance, managed by the person who provides for the family, a significant part of the management levels are filled by family members, where family members are largely influential in making decisions and where at least two generations of the family are employed in the institution. Families dominate the companies operating in Turkey. Everyone in Turkey is actually a family business. Being a family business can't be an obstacle to differentiation (Koç, 2008: 4958). There can be a difference between being a good company and not being a good company. Is there any guarantee that professional firms will succeed, that the family is not involved? There's no such thing. There, too, instead of family domination, the dominance and rigidity of the professional may come. The job of a company without family is very difficult (http://www.kobifinans.com.tr).

In the new world order, which is subject to changes every day with globalization, competition has extended beyond borders with the lifting of borders economically and the countries of the world establishing unions and transferring their sovereignty to semed institutions. This situation has forced small and medium-sized enterprises to be managed in the strategic management process and even made some changes in the strategies they implement.

Small and Medium Enterprises that are trying to make a profit, generate sales revenue, social responsibility and move forward in harsh competitive conditions need to determine in advance how they will proceed in the future with a more dynamic, healthy environmental analysis in order to sustain their lives.

One of the most important conditions of SMEs in maintaining their creative, growth and assets is finance. The resource problem is the biggest challenge for SMEs in maintaining their market share and opening up to the outside world. In many countries, SMEs use two main financing ways to address the resource cost problem: borrowing and capital raising.

SMEs often have problems taking advantage of different financing alternatives and balancing financing paths. These problems also affect the relationships between SMEs and those who provide financial support to them. As a result of the evaluation of past years, it has been seen that the financial resources provided by the banking sector are not sufficient for the development and growth of SMEs (Çolpan, 2005).

\subsection{Weaknesses and Strengths of SMEs}

SMEs have many weaknesses and strengths in the face of large enterprises due to their characteristics (Dinçer and Yahya, 2003: 71).

\subsubsection{Weaknesses of SMEs}

SMEs need to evaluate their current situation and characteristics in the globalization process and enter into a strategic structure in a way that gains competitiveness. Small business entrepreneurs often start 
their business life with a limited equity. In most cases, this capital is not even enough for the flow of fixed values and working capital required for the organization. Therefore, these businesses cannot be established at the optimum size. There are some features that leave SMEs powerless/weak in the face of large-scale enterprises and put them in a more disadvantaged position. these features are generally (Akgemci, 2001:16; Keskin and Şenturk, 2010:127; KSEP, 2011:38-39);

- They are affected by sales fluctuations,

- They are affected by a negative competitive environment,

- Depends on a single manager in decision-making,

- There is a risk of losing independence and going bankrupt,

- There are structural deficiencies in the enterprise,

- Funding sources are limited, they have difficulty obtaining,

- Marketing is viewed only as sales,

- They are not sufficient in management, accounting and production.

- Low levels of collaboration and efficiency.

- The level of training of SME managers and the quality of their employees are not at the desired level.

In this context, attention has been focused on three areas in order to eliminate the weaknesses and threats of SMEs in Turkey (Keskin and Şenturk, 2010: 127). To briefly explain these areas: Financing: Increasing the share of SMEs in the total volume of bank loans. Non-financial support: Providing services to SMEs receiving loans in order to improve and expand the quality of services provided, Technology: To increase the technological level of SMEs through R\&D support to support the technological infrastructure development of training programs and enterprises.

\subsubsection{Strengths of SMEs}

SMEs that can closely monitor the market, know the needs of customers better and establish closer relationships with their staff have more flexibility in production, marketing and service than the elders. Since this flexibility allows them to adapt on-site and in a timely manner to changes that may occur in the external environment, SMEs can avoid many negativity with less harm.

We can list the strengths of small businesses against large enterprises and their contribution to the economy as follows (Sabuncuoğlu and Tokol, 1995: 38; Akgemci, 2001: 15; Dinçer and Yahya, 2003: 72; Civan and Tekinkuş, 2005);

- They have a flexible structure, they can easily adapt to the personal tastes and trends of consumers, the requirements of fashion and change their production subjects according to consumer trends,

- They're more prone to innovation, but they may have financial difficulties,

- With technical changes, they can output more with fewer inputs,

- They have an advanced human relations and organizational climate,

- Since production is not much, there are not many storage and after-sales problems,

- In production, they can fill gaps between various units faster.

- There are fewer staff and bureaucracy, 
- They help encourage personal savings,

- They produce the basic materials necessary for large enterprises more quickly,

- They help encourage competition,

- They contribute to balanced development between regions,

- They have limited market space,

- They provide quick decision-making and competitive opportunities.

\section{BASIC PROBLEMS EXPERIENCED by SMES}

Companies are able to; their current and potential strength, from production to the release phase, is an important indicator for size when financing structures are considered as a research subject. The difficulty of classifying businesses as large and small is obvious. Moreover, regardless of size, businesses are united in common; to grow up and live.

From the point of view of the enterprises in Turkey, the financing structure of the enterprises in the developing Turkish industry has not yet reached a balanced and positive position. While the share of equity in the financing structure of enterprises has decreased gradually, the amount of foreign resources has increased considerably. In short, the equity-debt ratio of enterprises remains well below the standards for a period of time. There are many reasons for this. Inadequate savings, lack of capital accumulation, prevalence of the idea that the borrower wins in inflation, the lack of capital market development, the lack of medium and long-term lending institutions and institutions, limited financial powers are the main reasons that disturb the balance in the financial structure.

Research on the weaknesses of SMEs due to their structural characteristics reveals that these problems can be collected under five headings: production, marketing, legal and bureaucratic, Human Resources and Administrative and financial problems (Sabuncuoğlu and Tokol, 1995: 39; Mecek, 2021: 63).

\subsection{Production Problems of SMEs}

One of the most prominent features of globalization in production can be said to be the emergence of new industrial production organizations equipped with programmable automation technologies due to technological developments (Eser, 1995: 7). Advanced technological system are process technologies and management systems aimed at increasing the function of the design and production functions of the company (Koç, 1993: 212). As the level of technology has evolved, as it has progressed, the dependence of production processes on simple labor has decreased significantly. In manufacturing, the human element is replaced by manufacturing systems consisting of computers in terms of software and equipment with high integration capabilities.

It can be said that SMEs in Turkey generally continue their activities with old technologies based on labor. In addition, these businesses lack the opportunity to provide qualified workforce to keep up with technology. One of the main problem areas of SMEs is the problems experienced during the production phase. We can list the production problems of SMEs with the main headings (Öçal et al., 1990: 134-135; Turan and Gökalp, 1993: 8; Şahin and Özüdoğru, 2019: 322-323);

- Lack of Technology.

- The need for financing and qualified personnel in order to follow technological developments is a major obstacle for SMEs.

- Failure to meet quality norms.

- Inability to mechanize due to lack of capital.

- Lack of advanced management knowledge to implement new production technologies. 
- Monopoly firms are constantly raising input prices due to high inflation or excessive profits.

- SMEs, which are extremely weak against suppliers in monopoly positions, have to work completely dependent on these enterprises for their delivery times, amounts of goods to be received and prices.

\subsection{Marketing Problems of SMEs}

In the world of economics, where competition has reached incredible levels, it is seen that SME owners still act with the logic of "I sell what I produce" and do not understand the importance of marketing function. Today's strategic marketing approach of SMEs has to be customer-oriented.

\subsubsection{Problems Arising from Inadequate Marketing Activities and Lack of Information}

SMEs are suffering. Problems are not only experienced in the field of investment and operating capital financing, but also in the development of human resources, access to the market and access to modern technology and information. Both internal and external factors prevent the use of financing sources. Domestically, many SMEs lack credit reputation and management capacity, so they have difficulties obtaining funds for operations such as the provision of raw materials and products, investment in factories and equipment (Kandemir, 2003: 111).

One of the most important shortcomings of SMEs is that they do not benefit sufficiently from marketing tools (market research, advertising, after-sales services, etc.)(Korkmaz, 2003: 7). Marketing activities such as determining the target market or market sections required for the products to be produced, determining customer preferences, carrying out design studies, quality control, packaging, delivery of orders are not given enough importance (Demir and Şahin, 2000: 4; Yurdakul, 2003: 188). The main cause of all negativity is the financial constraints and lack of knowledge about it (Bağriaçık, 1989: 22).

Due to difficulties in the provision of information and inadequacies in the evaluation of the information obtained, SMEs are unable to keep up with technological changes and cannot take the necessary measures. Normally, SMEs have the ability to keep up with flexible production and change more quickly thanks to their flexible structures, but due to limited financing opportunities, they either reach information late or do not reach information at all because their sources of information are expensive (Oktay and Güney, 2002: 6).

Companies are having problems because they cannot easily find the qualified personnel they need. Since they are inadequate in training substitutes, when the employee trained through in-service training in the company leaves the job, the manufacturers are in a difficult situation because there are no substitutes to compensate (Gürak and Azakl1, 2000: 47). Vocational High Schools and Apprenticeship Training Centers are not sufficiently met for qualified and technical staff because the members do not provide training for the needs. In addition, the shortage of institutions that provide foreign language education in particular leaves exporting companies in a difficult situation (Akay et al., 2003: 8).

Due to the lack of cooperation and partnership in manufacturing companies in the same and similar sectors, there is difficulty in the formation of social capital. Since productivity cannot be achieved from previous partnership and cooperation studies, social capital formation in companies and entrepreneurs remains weak and individuality is at the forefront. Members do not have sufficient access to information about the activities of professional institutions (chambers of commerce, exchanges, unions) and are inadequate in terms of active membership.

\subsubsection{Problems Arising from Inadequate Cooperation Between SMEs}

In the areas where SMEs operate, the large number of enterprises and the easy entry and exit of the market leads to the formation of prices that are not affected on an individual business basis. This causes businesses to be much more sensitive to changes in market conditions and to face great 
difficulties, especially in the face of increases in input prices. Due to the importance of SMEs to their independence and lack of communication between enterprises, their inability to establish partnerships for domestic and foreign markets leave these enterprises at a competitive disadvantage to large enterprises and cause their costs to rise (Bağrıaçık, 1989: 22).

While the fact that SME owners are usually the primary managers of their businesses is an advantage in accelerating business and adapting to changes, the lack of professional and technical information required in the face of ever-changing market conditions and technologies makes it difficult to make timely and accurate decisions. It is seen that SME owners do not understand the fact that information is an important input. Despite this negativity in the field of information, the shortcomings in the employment of specialist staff make the current situation more difficult and the chances of SMEs competing are decreasing (Bağriaçık, 1991:141-142).

\subsection{Legal and Bureaucratic Problems of SMEs}

Another problem of SMEs is due to their legal structure. For example, if you're going A SME wishing to issue securities must have the status of A.Ş. (joint stock company). However, the vast majority of these organizations are limited or private companies. Therefore, SMEs; not only is he trying to get into the capital market, he can't even get this issue on their agenda (Ekinci, 2003).

SMEs face bureaucratic barriers in their relations with public institutions, both during the establishment and during their activities. The lack of full cooperation and coordination between public institutions dealing with SMEs leads to confusion of concepts, prolonged work and ultimately a waste of time and money. SMEs complain more about the multiplicity of unnecessary treatments in their relations with government offices. In addition, problems created by regulation and similar legislation, such as the very slow operation of the system, are among the most complained about issues. On the other hand, SMEs that are oriented towards exports are not supported against the bureaucratic obstacles they face at home and abroad and are left alone (Bağrıaçı, 1991: 165).

Even if the financial problems arising from their economic scale in SMEs are solved by external interventions such as production etc., the desired quality level in the field of management cannot be achieved. Management function and a weakness in managers will directly affect other functions of the enterprise and cause a large number of new problems to arise. In this case; It can be said that the main basis of the problems that SMEs are experiencing is the management structures of the enterprises (Soyhan, 1998: 72).

In order to develop solutions to the management characteristics of SMEs, it is necessary to list the characteristics related to the management function. These features include (Soyhan, 1998: 73; Gümüştekin, 2005: 82);

- The main feature of SMEs is that they are largely managed by owner-managers.

- Since the administrator retains authority, there is no transfer of authority or is transferred only for certain periods of time where necessary.

- The owner must have full authority and carry the full management responsibility

- SMEs have a direct relationship between the manager and the employees.

- The absence of hierarchical ranks or very few accelerates decision-making and increases flexibility.

- Since the owner is the one who determines the objectives and assumes all the risk, there is no conflict of interest and power struggle within the enterprise.

- In addition, short- and medium-term plans are usually discussed when setting objectives. 


\subsection{Human Resources and Administrative Problems of SMEs}

SMEs have an extremely important place for the economy. SMEs are of great importance for national economies due to their longevity and stable continued activities, their role as job creation and economic revival. In SMEs, the management process, decision-making mechanism is usually concentrated and shaped on a single person. There are advantages as well as disadvantages of collecting the management and responsibilities of the enterprise in a single person. The most important of these disadvantages is that managers within the enterprise have to take various roles such as accounting, sales personnel or human resources when the time comes, and they are incapable of keeping up with these points. The vast majority of SMEs have difficulty managing due to this situation and fail.

Various problems may arise if the powers and responsibilities of individals are not balanced. The financial management processes of SMEs, where the number of personnel is small and often specialist staff are not employed or under-employed, are not developed and institutionalized like large-scale enterprises (Mecek, 2021: 63). The main feature of SMEs is to produce based on labor force. SME owners often do not have the qualification of management. They try to see things themselves, as they will direct their business (Özgener, 2003: 146-147). The biggest problem here is the issue of wages. Human resources are not given importance in SMEs. It cannot be done in applications related to motivation methods of employees. Already the most obvious motivational tool is the fee. Due to the low wages, qualified personnel leave the enterprise with their knowledge (Şahin and Özudoğru, 2019: 326).

The inability of business owners to collect and evaluate information about the market, to avoid the employment of qualified personnel,not to transfertheir powers and not to want professional managers, prevents wrong decisions from being made and the creation of a flexible structure (Börü, 1997:177). In this case, many opportunities may be missed from a business point of view or the opportunities that have been seizedmay not be properly evaluated (Özgener, 2003: 139-140; Gümüştekin, 2005: 75).

\subsection{Financial Problems of SMEs}

SME owners who largely turn to their own resources to develop and grow; they suffer losses and lose their working capital due to inflation increase, competition and market shortages. This situation causes SMEs to have difficulties with market fluctuations, technological developments and growth.

Small businesses follow a variety of ways to provide funding. In general, these businesses do not resort to the money market, they use their own savings. If they have assets, they mortgage them and provide loans. These businesses often use leasing and similar methods to provide the necessary goods and equipment and try to overcome the financing difficulties in this way (Tandoğan, 1991: 31).

The initial capital of small businesses is usually covered by inadequate savings from entrepreneurs or consists of borrowed resources. Therefore, businesses face various financial difficulties during their operating periods. Due to lack of capital, they are unable to stock up, disrupting the production process and causing delays in delivery times, which leads to orders being canceled. Unstable price policies, excessive increases, problems with product quality and delivery conditions, and rate increases are causing SMEs trouble (Bağrıaçık, 1991:142-143; Uludağ and Serin, 1992: 23; Akgemci, 2001:28). We can collect the financial problems experienced by enterprises under two headings: problems in sourcing and problems with financial management.

\subsubsection{Problems in Sourcing}

SMEs are at a disadvantage compared to large enterprises in relation to the amount and maturity of loans. Banks are not very keen on lending to SMEs. Because they will deal with a large number of low-paid customers and increase their risk; they prefer to minimize their risks by engaging with a small number of high-stakes customers. Even if the loan is allocated, it usually has a maturity of 1 year or less, thus not allowing the small industrialist to expand his business and keep up with new technologies. However, SMEs also need long-term loans (Ekinci, 2003). The financing problem of 
SMEs is the most fundamental problem. Although SMEs have obligations to provide financial resources, they face many problems in achieving this. The main reasons why SMEs are experiencing these problems are as follows (Kutlu and Demirci, 2007:190-193; Kurt and Öztürk, 2008:43; Can, 2012: 22-23; Zengin and A $\breve{g}, 2016: 233-234)$;

- Organization of bank loans and capital markets to serve large enterprises in the provision of funds,

- When lending, banks should look at the guarantees to be shown by the owner or partners, not by project or performance,

- Machinery, machinery, tools and equipment that are requested and available on a real estate mortgage are not accepted as collateral,

- High loan interest rates,

- SME owners want to protect their independence and not welcome new partnerships,

- Insufficient sources of auto financing consisting of operating profits and depreciations,

- Their use of labor-intensive technologies and therefore low auto financing through depreciations.

\subsubsection{Problems in the Field of Financial Management}

Small and Medium Enterprises face very different problems financially than large-scale companies based on their scale, the main reasons why SMEs face financial difficulties are the problems caused by business managers. In particular, the fact that the owner has undertaken all the work as a business manager results in the emergence of problems on a larger scale (Arslan, 2003). Due to the lack of knowledge and experience of business managers in SMEs in financial management, these companies often lack staff in financial matters, unlike large-scale companies (Atik and Sezer, 2001).

It is also very difficult for SMEs to take advantage of capital market opportunities (Bulmuş et al., 1990). Financial institutions ask for high guarantees to enter into a credit relationship with businesses they consider risky. However, in these loans, SMEs have problems with maturity, limit, interest rate. This puts businesses in a vicious circle. If a business has added its winnings to its capital and has not acquired real estate, the chances of getting a loan are diminishing, perhaps none at all. In addition, the first thing financial institutions do in the crises is to stop the use of loans and to recall existing loans. All this increases the financing difficulties of SMEs (Bayraktar and Köse; 2002). The problems that businesses have experienced in the field of financial management are as follows (Kandemir, 2003: 14);

- Lack of a financing department as in large enterprises,

- Since it is seen as a great cost for the business, the employment of financing specialists is not included,

- Due to these shortcomings, financial alternatives and credit conditions cannot be adequately examined,

- Calculations regarding receivables, inventories, income and expenses are carried out irregularly and unplanned.

Financial problems are effective throughout the entire life cycle of the enterprise starting from the establishment stage. This structure is directly connected to all elements of the chain formed by functions in the enterprise. Any possible problems may affect the entire structure. 


\section{FINANCIAL FAILURE OF SMEs and SOLUTION PROPOSALS}

SMEs have many problems such as structural, management, production and adaptation to new technologies, as well as low capacity work, procurement and stockpiling, information support and technical assistance, marketing and competition, inability to make new investments, inadequacies in legal regulations and bureaucratic obstacles. However, the focus of all these problems is lack of financing. These problems, which started at the establishment stage, affect businesses throughout all their activities. On the one hand, there is not enough demand for products produced by SMEs due to inflation reducing real purchasing power, on the other hand, continuous increases in input costs prevent capital accumulation and allow production activities to be carried out with difficulty (Karabicak and Altuntepe, 2001: 286).

As it is known, the capital put into operation by entrepreneurs or partners alone and the part of the venture gain left in the enterprise and the reserves constitute the equity of the enterprise. While the low level of national income per capita in our country reduces the tendency to save money, there is no capital to finance investments and new investments are negatively affected. For this reason, existing enterprises in an effort to keep up with growth and developing technology face a financing problem.

Especially during periods of high conjunctural fluctuations, SMEs' equity is gradually decreasing and businesses provide all production inputs, including the labor they need while continuing their production activities, with upfront payment and offer their products to the market with certain maturities. Economic inactility and market congestion disrupt the collection of enterprises and sometimes even leave them unable to collect at all. The rise of cash shortages is either driving businesses towards expensive sources of financing or causing their capital to gradually melt away.

In general, SMEs, which use more manual labor besides low capital use, are capable of quick decisionmaking, work with low management costs and are expressed as economic enterprises that carry out cheap production, have more advantages than large companies in many cases (Uludağ and Serin, 1990: 14).

Regardless of the level of economic development, SMEs in all countries form the backbone of economic and social order both numerically and in terms of job creation (Doğan, Şengül, 2005: 291). Today, with the globalization of world markets, developed and developing countries are becoming more aware of the flexibility and capabilities of SMEs to adapt to social and economic changes, and as a result, implement incentive measures to increase their competitiveness and technological levels (Iraz, 2005, 227; Ay, 2008).

For the short-term resources that SMEs need, financial institutions are not too eager to use their own resources. Various Banks have short-term business loan activities for SMEs. The demand for loans is subject to such conditions by banks that financing subsidies are directed only to large businesses that can comply with these conditions. The equity of these enterprises is inadequate and banks have difficulty obtaining loans from banks due to their strong collateral demands and insufficient equity of these enterprises (Canbaş, 1998). In addition, the small turnover of these companies leads to low creditworthiness. It is seen that SMEs face the most "inability to provide collateral" in financing through credit and cannot meet the mortgages or guarantees that the credit institutions they apply for in order to meet their short-term financing needs are required to lend (Çelik, 2007: 31).

Although SMEs make up the majority of the Turkish economy, they are unable to use existing financing methods to finance their investments and cannot provide long-term loans because of the low share of total loans (Akbulut, 2000). The inability of SMEs to adequately benefit from capital market opportunities is another financing problem, likewise, SMEs hardly benefit from modern financing techniques such as leasing and factoring (Özgen and Doğan, 1997).

Considering that the medium-term lending rate is low in our country, it is observed that SMEs try to cover their investments with more equity, seller loans and short-term bank loans without using medium-term loans. In cases where SMEs are also inadequate to invest in equity, they can enter the 
financial crisis with the arrival of repayment periods of loans before they reach the production stage as a result of their shift to short-term bank loans instead of medium-term loans (Y1lmaz, 2006).

The solution of the financing problem of SMEs alone is not enough. In terms of factors affecting the opening of businesses to new markets; while the most important factor for non-exporters is economic and financial problems; the most important factor for exporters are bureaucratic obstacles. Especially SMEs with a small number of personnel and operating in the Central Anatolia Region need more economic and financial support (Karadal, 2001:156).

In addition to financial management practices, working capital management is of great importance for small-scale firms that are financially sensitive. Because working capital management has the effect of reducing the liquidity risk of the company, expanding the volume of work, increasing its creditworthiness, ensuring the continuity of production, the profitable and efficient operation of its activities and financial security (Akgüç, 1994). In this context, since the inflation accounting system has not yet been introduced in general, there is an increase in tax burdens as a result of the resulting profits exceeding the market value of the book value (Sariaslan, 1994).

The small size of SMEs increases the risk of bankruptcy of these companies and, as a result, the capital cost of SMEs. It is seen that SMEs in Turkey have difficulty creating their own brands and marketing their own products. The lack of country image and brand greatly weakens the competitiveness of these business. Unless companies create their own brand and pay attention to quality production, it is impossible to gain a competitive advantage against these developments. Especially in competition with European countries with high levels of industrialization and technology, it has made it mandatory for SMEs to reduce costs and produce quality with advanced technology. Thus, SMEs will be able to adapt to developing technology and market conditions by increasing their competitiveness, aim to produce quality goods and create a higher added value in the economy.

\section{CONCLUSION}

Turkey has a very important potential for SMEs. The evaluation of this potential is of great importance for Turkish Industry to adapt to the European Union, especially after the Customs Union. Therefore, it is necessary to identify the main problems of SMEs, especially management problems, and to develop effective solutions to the problems.

A number of structural problems such as Yprefix, manufacturing and new technology adaptation problems make it difficult for SMEs to maintain their economic presence. Therefore, it is urgently necessary to introduce economic and credit policies that will turn SMEs into rational enterprises in our country.

The credit opportunities of SMEs are very limited. As mentioned earlier, such businesses often provide their initial capital from personal and private sources of savings. In our country, the loans provided by manufacturing industry enterprises from banks are extremely inadequate within the overall lending volume. Today, the interest rates applied to SMEs are quite high. Investing at these high interest rates is no longer attractive. No business has the courage to develop its business with credit if the value it pays in interest is higher than the return it will provide. Therefore, interest rates applied to SMEs should be reduced.

The presence of high inflation in a country also pushes businesses to a lack of equity. The most important negative effect on working capital during periods of high inflation is that it does not allow the protection of working capital. In an economy under pressure from inflation, all of the inputs subject to production are increasing and increasing production costs. The negative impact of inflation on working capital is even more pronounced, especially in fixed investments. In inflationary periods, the business may face a larger capital problem in order to return the same business. 
Small industrial enterprises are trying to close their financing gaps primarily through autofinance due to insufficient equity and high credit costs. However, when there is a lack of equity, it is unlikely to expect a business to meet the capital deficit through autofinance, especially in inflationary periods. Banks undoubtedly play the most important role in the credit policies implemented in Turkey. It is a known fact that capital markets in our country are not developing sufficiently, legal regulations are inadequate, and SMEs cannot be incorporated to the extent that they can be opened to the public. By opening SMEs to the public, it is not possible in the short term for them to easily provide the funds they need for their development and growth from non-bank capital markets. For this reason, such businesses often turn to banks for their credit needs.

It is very important that SMEs, which are of great importance for the economy, can use existing resources effectively and efficiently in addition to providing resources to increase their share in the fields of production and employment in the country. Accordingly, it is necessary to raise the awareness levels of SMEs in working capital and financial management issues, to eliminate information deficiencies and to have easier access to incentive and credit facilities, as well as to research and use new financing techniques such as factoring and leasing. Thus, SMEs will be able to use their short and long-term resources in the most effective way and will achieve a more successful level in the working capital method.

In the face of globalization, digital information economy, rapidly changing communication technologies, new market opportunities and business activities and developing enterprisesthat are becoming increasingly complex in an environment of economiccrises, the lack of knowledge and skills of business founders and family members makes it difficult to adapt to change. In addition, since the emergence of new specialties, knowledge becomes an important value, the relationship of enterprises with the environment becomes important and the complex situations occurring in organizational structures, professional managers selected from among the experts who will understand thed-education in the enterprises in a timely manner and who can react creatively to this change are increasingly needed.

Today, SMEs start with incomplete, inaccurate and inadequate information at the establishment stage, feasibility studies are made incompletely or mistakes are made that are impossible or very difficult to recover becausethey are based on sufficient information and enterprises are obliged to carry these errors as a burden on their backs for a long time. These and similar problemsare affected by environments such as increased competitionand globalization trends, which makes the solution of SMEs' problems more important and urgent.

\section{REFERENCES}

AKAY, Diyar; Dağdeviren, Metin; Haliloğlu, Necla; Kurt, Mustafa and Taş, Nilgün F. (2003), “Türkiye'de KOBİ'ler İçin Eğitim Hizmetleri Pazarı”, KOSGEB-Avrupa Eğitim Vakfı Araştırma Projesi Raporu, KOSGEB Girişimciliği Geliştirme Merkezi, Ankara.

AKBULUT, Esin (2000). KOBİ'lerin Sermaye Piyasası'na Katılımı, İstanbul: IMKB Eğitim ve Yayın Müdürlüğü.

AKGEMCI, Tahir (2001), KOBİ'lerin Temel Sorunları ve Sağlanan Destekler, KOSGEB Yayınları, Ankara.

AKGÜÇ, Öztin. (1994), Finansal Yönetim. İstanbul: Muhasebe Enstitüsü Yayınları, Yayın No:63.

ARSLAN, Özgür (2003), "Küçük ve Orta Ölçekli İşletmelerde Çalışma Sermayesi ve Bazı Finansal Yönetim Uygulamaları”, C.Ü. İktisadi ve İdari Bilimler Dergisi, S.4(1), pp.121-135. 
ATIK, Hayriye and SEZER, Sevgi (2001), “Avrupa Birliği’ne Entegrasyon Sürecinde Küçük ve Orta Boy İşletmelerin Sorunları: Kayseri ve Nevşehir Örneğii”, I. Orta Anadolu Kongresi, “KOBİ'lerin Finansman ve Pazarlama Sorunları", 18-21 Ekim, Nevşehir, pp.107-116.

AY, Sema (2008) “Türkiye'deki KOBİ’lerin Finansman Sorunları”. Paradoks, Ekonomi, Sosyoloji ve Politika Dergisi, S. 4(1), pp.1-8.

BAĞRIAÇIK, Atila (1989), "Dışa Açılma Sürecinde Küçük ve Orta Boy Firmalar” (Dünyada ve Türkiye'de), İstanbul: Dünya Yayınları No:44.

BAĞRIAÇIK, Atila (1991), "Başka Ülkelerle Karşılaştırmalı Olarak Türkiye'de Küçük ve Orta Boy Firmalar", Uluslararası Sempozyum 17 Mayıs, İstanbul Sanayi Odası Araştırma Dairesi Yayın No:1991/5, İstanbul.

BALI, Selçuk and GÜMRÜKÇÜ, Özge (2017), “KOBİ’lerde Finansal Yönetim Tekniklerinin Uygulanması ve Trabzon İli Gıda İşletmeleri Üzerine Bir Anket Çalışması”, Akademik Sosyal Araştırmalar Dergisi, S.5(46), pp.1-21.

BAYRAKTAR, S. and KÖSE, Y. (2002), “KOBİ’lerin Finansmanı ve Finansal Sorunları: Zonguldak Örneği’”, 21. yy. da KOBİ'ler: Sorunlar, Fırsatlar ve Çözüm Önerileri Konferansı, 3-4 Ocak, Kıbrıs: Doğu Akdeniz Üniversitesi İşletme ve Ekonomi Fakültesi İşletme Bölümü.

BÖRÜ, Deniz (1997), “Küçük ve Orta Ölçekli İşletmelerde Profesyonel Yönetici Kullanımına İlişkin Bir Araştırma”, Öneri Dergisi, S.1(6), pp.177-186.

BULMUŞ, İsmail; OKTAY, Ertan and TÖRÜNER, Mete (1990), "Küçük Sanayi İşletmelerinin Konumu, Önemi ve At'a Girerken Karşılaşılabilecek Sorunlar ile Çözüm Yolları”. Ankara: MPM Yayınları, Yayın No:426.

CAN, Ali Necmettin (2012), Girişim Sermayesi ve KOBİ’lerde Uygulanabilirliği, Yayınlanmamış Yükseklisans Tezi, Sakarya Üniversitesi, Sakarya.

CANBAŞ, Serpil (30 Kasım- 3 Aralık 1989), "Küçük ve Orta Sanayi İşletmelerinin Finansal Sorunları ve Türkiye'de ve Avrupa'da Küçük ve Orta Sanayi İşletmelerine Sağlanan Finansal Destekler”, Kapadokya: 3.Ulusal İşletmecilik Kongresi.

CIVAN, Mehmet and TEKINKUŞ, Mehmet (2002), "Küçük ve Orta Boy İşletmelerin Avrupa Birliğine Uyum Süreci; Gaziantep Örneği”, ERC/ODTÜ Uluslararası Ekonomi Kongresi. VI. Bildiri Kitabı: Ankara.

ÇELİK, İsmail (2007). “Basel II Bağlamında KOBİ’lerin Finansman Sorunları: Tekstil Sektöründe Bir Uygulama”. Yayımlanmamış Yüksek Lisans Tezi. Süleyman Demirel Üniversitesi Sosyal Bilimler Enstitüsü, Isparta.

ÇOLPAN, Berna (2005). “Amerika Birleşik Devletleri’nde Küçük ve Orta Büyüklükteki İşletmelerin Finansmanı”, http://www.kobinet.org.tr/hizmetler/bilgibankasi/finans/006_1.html, 6 Haziran 2005, (Access Date: 28.12.2019).

DEMIR, Hulusi and ŞAHIN, Ayşe (2000). "Küçük ve Orta Ölçekli İşletmelerin (KOBİ) Pazarlama Problemleri İçin Bir Çözüm Önerisi: Niş Pazarlama”, Pazarlama Dünyası, S.14(5), Eylül-Ekim.

DİNÇER, Ömer and FIDAN, Yahya (2003), İşletme Yönetimine Giriş, İstanbul: Beta Basım Yayım Dağıtım A.Ş.

DOĞAN, Seyhun and ŞENGÜL, Ebru (2005), “Avrupa Birliğine Giriş Sürecinde Türkiye'de KOBİ'lerin Finansman Sorunlarının Çözümünde Girişimcilik Teşvikleri ve Destek Programları", Avrupa Birliğine Giriş Sürecinde KOBİ’ler: Türkiye ve Benzer Ülke Deneyimleri Sempozyumu, 19-22 Mayıs 2005 Balıkesir Üniversitesi, Bandırma İİBF Bandırma, 
SÜMERLİ, Sarıgül - Financial Problems of Small and Medium Enterprises (SMEs) and Solution Suggestions

EKİNCİ, Mehmet Behzat (Ekim 2003), “Türkiye'de Küçük ve Orta Ölçekli İşletme (Kobi)lerin Finansal Sorunları; İşletme İçinden ve Dışından Kaynaklanan Sorunlar", http://www.akademiktisat.net/calisma/isletmeler/kobi_finans.htm, (Access Date: 10.03.2020).

ESER, Uğur (1995), “Küreselleşme: Tehdit mi? Yoksa Fırsat mı?”, Ekonomik Yaklaşım, S.6(17), pp. $5-20$.

GÜMÜŞTEKIN, Gülten Eren (2005), "KOBİ Niteliğindeki Aile İşletmelerinin Yönetim ve Organizasyon Sorunları: Kütahya Seramik Sanayi Örneği”, Cumhuriyet Üniversitesi İktisadi ve İdari Bilimler Dergisi, S.6(1), pp.71-93.

GÜRAK, Hasan and AZAKLI, Sedat (2000), Nazillideki KOBİ'lerin Genel Durumu ve Sorunları, Nazilli Ticaret Odası Çalışma Raporu No: 1.

İRAZ, Rıfat (2005), "Küresel Rekabet Ortaminda Küçük ve Orta Büyüklükteki İşletmelerin Ulusal Sosyo-Ekonomik Sisteme Katkilari Açisindan Değerlendirilmesi, Selçuk Üniversitesi Sosyal Bilimler Enstitüsü Dergisi, S.(13), pp.223-236.

KANDEMİ, Ahmet (Aralık 2003), “Gelişmekte Olan Ülkelerde KOBİ'lerin Rekabet Edebilme Gücünün iyileştirilmesi Girişimin Gelişmesini Artırmada Finansmanın Rolü”, Ankara: Türkiye Kalkınma Bankası Araştırma Müdürlügü Yayınları, http://www.tkb.com.tr/esa/GA/2003-GA/GA-0309-17_GOUde_KOBIlerin_Rekabet_Gucu, (Access Date: 10.03.2020).

KARADAL, Himmet (2001), "KOBİ'lerin Uluslararası Pazarlara Açılmasını Etkileyen Faktörler Üzerine Bir Araştırma", I. Orta Anadolu Kongresi "Kobi'lerin Finansman ve Pazarlama Sorunları", 18-21 Ekim 2001, EÜ Nevsehir IIBF, Nevşehir, pp.189-199.

KARABICAK, Mevlüt and ALTUNTEPE, Nihat (2001), "KOBİ'lerin Kredi Yoluyla Finansmanı”, 1. Orta Anadolu Kongresi- KOBİ'lerin Finansman ve Pazarlama Sorunları, KOSGEB Yayınları, Nevşehir, http://www.kobinet.org.tr/hizmetler/bilgibankasi/ekonomi/OAKDocs/OAK-T28.pdf, (Access Date: 03.05.2020).

KESKIN, Hidayet and ŞENTÜRK, Canan (2010), "Küçük ve Orta Ölçekli İşletmelerin Ekonomideki Önemi: Türkiye ve Arnavutluk KOBİ Sektörü GZFT Analizi”, Niğde Üniversitesi İ.İ.B.F Dergisi, S.3(1), pp.116-132.

KOÇ, İdil Özlem (2008), Türk KOBİ'leri, Bugünü ve Geleceği. İstanbul: Arıkan Basım Yayım Dağıtım.

KOÇ, Tufan V. (1993), “Türkiye'deki Sanayi İşletmelerinin Rekabet Gücü ve Strateji Açısından Teknoloji Faktörü”, 93 Sanayi Kongresi Bildiriler Kitabı, TMMOB, 1. Cilt, Yayın No: 160, Ankara.

KORKMAZ, Sezer (2003), "Küçük ve Orta Ölçekli İşletmelerin (KOBİ) Pazarlama ve Finansman Sorunlarının Çözümünde Risk Sermayesinin Kullanılabilirliği Üzerine Bir Araştırma", Ticaret ve Turizm Eğitimi Fakültesi Dergisi, S.2, pp. 233-266.

KSEP (2011), 2011 - 2013 KOBİ Stratejisi ve Eylem Planı (KSEP). Yüksek Planlama Kurulu Kararı. (15.07.2011 tarih ve 27995 sayılı Resmi Gazete).

KURT, Ganite and ÖZTÜRK, Veli (2008), "Basel II ve Yeni Türk Ticaret Kanun Tasarıs1 Çerçevesinde KOBİ'lerin UFRS'ye Uyum Gerekliliği ve Karşılaşılabilecek Sorunlar ve Çözüm Önerileri”, Muhasebe ve Denetime Bakış Dergisi, S.24(1), pp.37-54.

KUTLU, Hüseyin Ali and DEMIRCI, N. Savaş (2007), "KOBİ'lerin Finansal Sorunları ve Çözüm Önerileri”, 4. KOBİ'ler ve Verimlilik Kongresi, İstanbul Kültür Üniversitesi, 7-8 Aralık, pp.187-198.

MECEK, Gülsevil (2021), “Türkiye'de KOBİ'lerin Teşvik Edilmesi ve Desteklenmesi”, Premium EJournal of Social Sciences (PEJOSS), S.5(11), pp.53-65. 
MECEK, Mehmet (2013), "Kamu Kurumları ve Kamu İdarelerinin Tarihsel Süreç İçerisinde Girişimcilik Üzerine Etkileri”, Uluslararası Girişimcilik ve Kariyer Sempozyumu Bildiriler Kitabı, Muğla, pp.487-509.

MECEK, Mehmet and AKIN, Fehmi (2014), "Kamu İdarelerinin Girişimcilik Aracı Olarak Kamu İşletmeleri”, 6.Uluslararası Girişimcilik Kongresi Bildiriler Kitabı, Bişkek (Kırgızistan), pp.89-99.

OKTAV, Mete; KAVAS, Alican; ÖNCE, Günal and TANYERI, Mustafa (1990), "Orta ve Küçük İşletmelerde İhracata Yönelik Pazarlama Sorunları ve Çözüm Önerileri”. Ankara: TOBB Yayın No: Genel 176; Ar-Ge: 79.

OKTAY, Ertan and GÜNEY, Alptekin. (2002), “Türkiye'de Kobi'lerin Finansman Sorunu ve Çözüm Önerileri”, “21. yüzyılda KOBİ'ler: Sorunlar, Fırsatlar ve Çözüm Önerileri” Sempozyumu, 03-04 Ocak 2002, Doğu Akdeniz Üniversitesi, K.K.T.C.

ÖÇAL, Tezer; BULMUŞ, İsmail; OKTAY, Erman. and TÖRÜNER, Mete (1990), "Küçük Sanayi İşletmelerimizin Konumu, Önemi ve AT'a Girerken Karşılaşılabilecek Sorunlar ile Çözüm Yolları”, MPM Yayınları, Yayın No:426, Ankara.

ÖZDEMIR, Süleyman, ERSÖZ, Halis Yunus and SARIOĞLU, Halil İbrahim (2006), “İşsizlik Sorununun Çözümünde KOBİ'lerin Desteklenmesi”, İstanbul: İstanbul Ticaret Odası (ITO) Yayınlar1.

ÖZDEMIR, Süleyman., ERSÖZ, Halis Yunus and SARIOĞLU, Halil İbrahim. (2011), "Küçük Girişimciliğin Artan Önemi ve KOBİ'lerin Türkiye Ekonomisindeki Yeri”, Sosyal Siyaset Konferansları Dergisi, S.53, pp.191-203.

ÖZGEN, Hüseyin and DOĞAN, Selen (1997), "Küçük ve Orta Ölçekli İşletmelerin Uluslararası Pazarlara Açılmada Karşılaştıkları Yönetim Sorunları ve Çözüm Önerileri”, KOSGEB Yayınları Ankara,

ÖZGENER, Şevki (2003), "Büyüme Sürecindeki KOBİ'lerin Yönetim ve Organizasyon Sorunları: Nevşehir Un Sanayii Örneği”, Erciyes Üniversitesi İiBF Dergisi, Say1:20, Ocak-Haziran 2003, pp.133-161.

SABUNCUOĞLU, Zeyyat and TOKOL, Tuncer (1995), İşletme- I (Temel Bilgiler), Bursa: Rota Ofset Yayıncilık.

SARIASLAN, Halil (1994), “Orta ve Küçük Ölçekli İşletmelerin Finansal Sorunları: Çözüm İçin Bir Finansal Paket Önerisi” Ankara: TOBB Yayınları, No:281.

SOYHAN, Cavit (1998), "Küçük ve Orta Boy İşletmelerin Yönetsel Sorunları ve Çözüm Önerileri”, İstanbul: Marmara Üniversitesi, Yayınlanmamış Yüksek Lisans Tezi.

ŞAHIN, B. Deniz and ÖZÜDOĞRU, Haşim (2019), “KOBİ'lerde Üretim ve Pazarlama Sorunları: Ostim Örneği”, Üçüncü Sektör Sosyal Ekonomi Dergisi, S.54(1), pp.320-333.

ŞEKER, Ayberk, DOĞAN, Mesut and ELİTAŞ, Bilge Leyli (2016), "KOBİ’lerde Girişimcilik Değerleri ve Dış Ticaret Faaliyetleri Arasındaki İlişki: Sanayi İşletmeleri Örneği", İşletme Araştırmaları Dergisi, 8(2), 198-223.

TANDOĞAN, Uğur (1991), "Küçük İşletmelerde Finansman Sorunlar1 ve Çözüm Önerileri”. İzmir: Dokuz eylül Üniversitesi Sosyal Bilimler Enstitüsü İşletme Anabilim Dalı, Yayınlanmamış Yüksek Lisans Tezi.

TURAN, Güngör and GÖKALP, M. Faysal (1993), “Türkiye’ de Küçük ve Orta Ölçekli İşletmelerde Teknoloji Sorunu ve Çözüm Önerileri”, Dünya Gazetesi. 21 Kasım, pp.7.

ULUDAĞ, İlhan and SERİN, Vildan (1992), “Türkiye'de KOBİ'ler: Yapısal ve Finansal Sorunlar, Çözümler", İstanbul: Renk Basım Yayın. Yayın No: 21. 
YILMAZ, Hatice Biçen (2008), “KOBİ'lerin Finansman Sorunu ve Sermaye Piyasalarında Çözümü”, Paradoks Ekonomi, Sosyoloji ve Politika Dergisi, S.1(2), pp.8- 10.

YURDAKUL, Müberra. (2003), "Franshising Sisteminin KOBİ’lerde Pazarlama İşlevi Bakımından Değerlendirilmesi”, Dumlupınar Üniversitesi Soysal Bilimler Dergisi, S.8, Haziran 2003, pp. 1-12.

ZENGİN, Yunus and AĞ, Ali Rıza (2016), "KOBİ'lerdeki Başarıyı Etkileyen Finansman Sorunu: Neden Mi? Sonuç Mu? Literatür Taraması Sonucu Bir Değerlendirme”, Akademik Bakış Dergisi, S.(54), pp. 227-241.

http://www.isletme.biz/content/view/1238/27/ (Access Date: 28.02.2020).

http://www.kobi.org.tr/dosyalar/KOBI\%20Tanimi\%20Kanunu.doc. (Access Date: 28.02.2020).

http://www.kobifinans.com.tr/tr/bilgi_merkezi/0206/750/8. (Access Date: 28.02.2020). 